\title{
Turning up the heat: mechanistic insights into thermal photodynamic therapy
}

DOI:

10.1111/bjd.14735

\section{Document Version}

Accepted author manuscript

Link to publication record in Manchester Research Explorer

\section{Citation for published version (APA):}

Farrar, M. (2016). Turning up the heat: mechanistic insights into thermal photodynamic therapy. British Journal of Dermatology, 175(3), 458-459. https://doi.org/10.1111/bjd.14735

\section{Published in:}

British Journal of Dermatology

\section{Citing this paper}

Please note that where the full-text provided on Manchester Research Explorer is the Author Accepted Manuscript or Proof version this may differ from the final Published version. If citing, it is advised that you check and use the publisher's definitive version.

\section{General rights}

Copyright and moral rights for the publications made accessible in the Research Explorer are retained by the authors and/or other copyright owners and it is a condition of accessing publications that users recognise and abide by the legal requirements associated with these rights.

\section{Takedown policy}

If you believe that this document breaches copyright please refer to the University of Manchester's Takedown Procedures [http://man.ac.uk/04Y6Bo] or contact uml.scholarlycommunications@manchester.ac.uk providing relevant details, so we can investigate your claim.

\section{OPEN ACCESS}


Turning up the heat: mechanistic insights into thermal photodynamic therapy

M.D. Farrar

Centre for Dermatology, Institute of Inflammation and Repair, University of Manchester, Manchester Academic Health Science Centre, Manchester, UK

Correspondence: Dr Mark D. Farrar, Photobiology Unit, Dermatology Centre, University of Manchester, Salford Royal NHS Foundation Trust, Manchester, M6 8HD, UK. Tel.: +44 161 2060214, e-mail: mark.farrar@manchester.ac.uk.

ORCID: http://orcid.org/0000-0001-8602-7279

Conflicts of interest: None declared

Funding: None declared 
Topical photodynamic therapy (PDT) is commonly used in the treatment of nonmelanoma skin cancer and is favoured for ease of administration, tolerability and excellent cosmetic outcome. Treatment involves topical application of a prodrug, aminolaevulinic acid (ALA) or its methyl ester MAL, which is converted to the photosensitiser protoporphyrin (Pp) IX. Light-activation of PpIX initiates production of reactive oxygen species (ROS) and target cell death primarily via apoptosis. ${ }^{1}$ Treatment takes some hours as sufficient time must be given for prodrug penetration and PpIX accumulation, and efficacy is dependent on treatment protocol, type and site of target lesion(s). ${ }^{2,3}$ Application of heat during prodrug incubation has shown promise in improving PDT efficacy. In vitro, increased temperature led to greater PpIX accumulation ${ }^{4}$ while a clinical pilot study demonstrated greater clearance of actinic keratosis in heat-treated skin; ${ }^{5,6}$ there are no reports in Bowen's disease or basal cell carcinoma.

In this issue of the $B J D$, Mamalis et al. ${ }^{7}$ provide further mechanistic insight into thermal PDT. Using normal human fibroblasts in a series of in vitro experiments, they investigated how varying ALA concentration while maintaining constant temperature $\left(36^{\circ} \mathrm{C}\right)$, and varying temperature $\left(21-42^{\circ} \mathrm{C}\right)$ for a single concentration of ALA, impacted on PDT. Following ALA incubation and light activation, flow cytometry was used to examine for markers of apoptosis and necrosis, and to detect ROS. At $36^{\circ} \mathrm{C}$, an ALA concentration-dependent increase in the proportion of apoptosis-positive cells was seen with very few cells undergoing necrosis. This was associated with a similar concentration-dependent increase in production of superoxide species. When a single ALA concentration was used with varying temperature, both the proportion of apoptosis-positive cells and relative amount of superoxide species increased with increasing temperature. This work showed that increasing prodrug concentration or temperature heightened the photodynamic response at the molecular level. 
From their human fibroblast model, Mamalis et al. conclude that thermal PDT increases production of superoxide and the proportion of apoptotic cells in a temperature-dependent manner, and their data suggested that a temperature of $39^{\circ} \mathrm{C}$ was optimal. Further in vitro studies could explore these mechanisms using keratinocyte tumour cells lines as PDT is used to treat keratinocyte cancers and precancers. The authors speculate that thermal PDT may improve patient compliance and cost-effectiveness through reduced treatment times and increased efficacy. Temperature can be easily controlled in vitro, but maintaining a constant, raised temperature at the site of topical prodrug application may prove more challenging, although several methods are available. ${ }^{8}$ Moreover, any advantages gained through the potentially increased efficacy and efficiency of thermal PDT must consider the potential for increased pain and/or other adverse events that may result from a heightened photodynamic reaction, and may have implications for patient acceptability and compliance. The findings of Mamalis et al. and others will require translation to well-designed clinical trials to fully assess thermal PDT.

\section{Acknowledgements}

I am grateful to Professor Lesley Rhodes for helpful comments and suggestions. 


\section{References}

1. Oleinick N, Morris RL, Belichenko I. The role of apoptosis in response to photodynamic therapy: what, where, why, and how. Photochem Photobiol Sci 2002; 1:1-21.

2. Morton CA, Brown SB, Collins S et al. Guidelines for topical photodynamic therapy: report of a workshop of the British Photodermatology Group. Br J Dermatol 2002; 146:55267.

3. Morton CA, McKenna KE, Rhodes LE. Guidelines for topical photodynamic therapy: update. Br J Dermatol 2008; 159:1245-66.

4. Yang J, Chen AC, Wu Q et al. The influence of temperature on 5-aminolevulinic acidbased photodynamic reaction in keratinocytes in vitro. Photodermatol Photoimmunol Photomed 2010; 26:83-8.

5. Willey A, Anderson RR, Sakamoto FH. Temperature-modulated photodynamic therapy for the treatment of actinic keratosis on the extremities: a pilot study. Dermatol Surg 2014; 40:1094-102.

6. Willey A, Anderson RR, Sakamoto FH. Temperature-modulated photodynamic therapy for the treatment of actinic keratosis on the extremities: A one-year follow-up study. Dermatol Surg 2015; 41:1290-5.

7. Mamalis A, Koo E, Sckisel GD et al. Temperature-dependent impact of thermalaminolaevulinic acid photodynamic therapy on apoptosis and reactive oxygen species generation in human dermal fibroblasts. Br J Dermatol 2016; 175:512-19.

8. Mordon S. A commentary on the role of skin temperature on the effectiveness of ALAPDT in Dermatology. Photodiagnosis Photodyn Ther 2014; 11:416-19. 